УДК $81 ' 366.58$

\title{
MORPHOLOGY OF TENSE IN ENGLISH: VIEW FROM COGNITIVE LINGUISTICS
}

\author{
N.A. Besedina, S.N. Stepanenko, O.V. Fedotova \\ Belgorod State University (Belgorod, Russia) \\ SStepanenko@bsu.edu.ru
}

\begin{abstract}
This paper is an attempt to address morphological category of tense in English in the cognitive perspective by means of showing mechanisms of interaction between the conceptual and linguistic units.

The authors demonstrate how semantic changes originate in the conceptual processes exploiting the morphological tense forms to objectivize and represent a broad spectrum of lexico-grammatical categorical senses in the process of communication. To provide a description and explanation of these processes a cognitively-based theory of morphological representation, worked out within the framework of cognitive linguistics, is foregrounded.

The authors present a notion of morphological concept, model the process of morphological representation, single out mechanisms and factors influencing the formation of the new senses expressed by the tense forms in English. Finally, the research specially emphasizes the fact that the ability of tense forms to express a variety of meanings is caused by the conceptual processes, which underlie the morphological representation.
\end{abstract}

Key words: English morphology, tense forms, model of morphological representation, morphological concept, cognitive mechanism, linguistic factors, integrative principle, configuration, abstraction.

For citation: Besedina, N. A., Stepanenko, S. N., \& Fedotova, O. V. (2019). Morphology of Tense in English: View from Cognitive Linguistics. Voprosy Kognitivnoy Lingvistiki, 3, 85-95.

DOI: 10.20916/1812-3228-2019-3-85-95

\section{Introduction}

The aim of the present article is to provide a cognitive explanation of morphology of tense in English by examining the conceptual processes and cognitive mechanisms and factors that underlie the category of tense and its forms when they express different senses in the process of communication. First, we will review some basic issues regarding the process of morphological representation in general, and then determine the major points providing the fundamentals for our research.

The assumptions of prime importance taken into consideration in the present paper are as follows.

1. Cognitive linguistics presumes language as an instrument for organizing, processing and conveying information. Language forms are treated as an integral part of human cognition, language itself provides insights into the nature, structure and organization of thoughts and ideas. In this way, language is assumed to reflect patterns of thought, certain fundamental properties and design features of the human mind. It follows from this very assumption that it is impossible to study the language structure without taking into account its cognitive basis.
2. From the perspective of cognitive linguistics, conceptual and semantic levels are not identical. It refers to the differentiation of the non-linguistic level of conceptual representation and the level of linguistic representation, which enables the existence of the conceptual and linguistic worldviews. At the same time, this differentiation does not denote their absolute opposition, as they exist in a constant close interaction [Кубрякова, Демьянков 2007]. It results in semantics having two directions: towards the conceptual system and towards the language system and thus it performs the role of interface between a language and a conceptual system [Беседина 2006].

3. The human conceptual level is a single level of mental representation onto and from which all the peripheral information is mapped [Taylor 1995]. This level also serves as a universal basis of a language system and provides systematization, choice and combinability of linguistic signs to express certain thoughts and interpret them to understand different texts [Болдырев 2014]. Conceptual level is not only the system of concepts, conceptual groups and classes but also it is the level of categorical meanings and senses [Болдырев 1995]. The importance of categor- 
ical senses is that they, but not the single concepts, form the basis for grammatical (inter alia morphological) categories.

4. Cognitive linguistics considers linguistic meaning as a conceptual structure manifestation and an interpretation within the framework of a conceptual system as a whole [Болдырев 2014]. The two general observations seem to be relevant in this respect. The first is that a concept is dynamic and nonverbal by nature. It has a flexible structure, which, being in constant development, represents the results of a human cognition and is used in the process of speech-producing activity. The second is that not all the concepts gain linguistic representation that is verbalized. It enables us to differentiate verbalized and non-verbalized conceptual content and, consequently, a concept as a mental unit, existing as a nonstructured gestalt before its verbalization and a concept as a verbalized unit, from which it follows that a concept exists in two modes: as knowledge unit and as knowledge structure, indexed in linguistic forms (cf. [Беседина 2006]).

With the above generalities in mind, we will further consider some theoretical issues regarding the process of morphological representation and cognitive perspective of English Tense in particular.

\section{Fundamentals and method of the research}

Adopting a fresh perspective, we use conceptual-representative analysis as a newly-derived method of cognitive researches in linguistics [Беседина 2006; 2011]. Implying the further development of conceptual analysis this type of analysis aims at investigating the concept's content and role of each linguistic level in its representation. Thus, the analysis is carried out in two directions: from the conceptual content to the linguistic one and vice versa.

From a cognitive viewpoint, morphology is argued to be treated in terms of morphological representation and morphological concept, which are developed within the framework of a theory of morphological representation (see details in [Беседина 2006]). Morphological representation presupposes a categorical way of structuring conceptual content through morphological categories and forms. It is generally agreed that speakers may conceptualize the same experience in different ways. Morphological categories in their turn conceptualize or construe the experience of the speaker in the world in certain ways. This appears to be very much in line with the central hypothesis of cognitive semantics that much of language - grammatical inflections and constructions in particular - can be described as encoding dif- ferent conceptualizations of experience [Clausner, Croft 1999].

The basic theoretical construct of morphological representation is a morphological concept. From the assumption of a concept existing in two modes, mentioned above, it necessarily follows that, on the one hand, morphological concepts are the definite units of the categorical part of the conceptual level (for instance, TIME, QUANTITY), represented by means of morphological categories and forms. On the other hand, they are the concepts, creating the basis for morphological categories formation that are realized in a discourse in the form of concrete grammatical meanings (e.g. grammatical tense, number, aspect, mood, etc.). Taken together, morphological concepts make a cognitive basis for a morphological representation in a language [Беседина 2005].

Further, we will study the stages of morphological representation in detail. Conventionally morphological representation experiences some stages. The first stage of it is connected with the formation of morphological concepts. Our hypothesis is that they are formed on the basis of the concepts which already exist in the conceptual system. These concepts are of primary importance and salient position in the conceptual system, as they determine the very existence of the latter. In cognitive linguistics tradition they are usually termed fundamental concepts (see [Jackendoff 1984; Кубрякова 2004]). These are such concepts as TIME, QUANTITY, SPACE, RELATION, etc.

The cognitive mechanism, which serves to form morphological concepts, is that of abstraction. Under its influence the most generalized characteristics in the structure of primary concept are abstracted from the concrete ones and create a new concept (morphological concept). In this case, the latter may be treated as a secondary concept, embedded into the structure of the primary one. As a result, characteristics, which are the most important for the language, are encoded [Беседина 2006]. Accordingly, the content of morphological concepts is highly abstract. It results in generalized character of grammatical meanings conveyed by the morphological forms. Morphological concepts can be treated as classifying ones because they are oriented to the language system but not the world around us, coding the way the language maps the world. It gives the right to assume that morphology conceptualizes linguistic knowledge [Беceдина 2007; Besedina et.al 2014]. There is no definite correlation between a fundamental concept and a morphological concept. One fundamental concept may cause appearing of more than one morphological concept. For instance, fundamental concept TIME 
can give rise to morphological concepts TENSE and ASPECT.

It stands to reason that the process of morphological concept creation is based on the reorganization at a conceptual level with the help of such cognitive mechanism as abstraction. This human cognition mechanism is used to modify the concept already existing in the conceptual system and create a new one - a morphological concept, linguistic by nature. The way this is done is reflected at the linguistic level. Being rather abstract by nature a morphological concept presents gestalt itself, generalized and abstract conceptual characteristics of which demand further concretization. The latter becomes possible only in interaction with different linguistic factors in the process of morphological representation. So far, we have established that the essence of morphological concept is that its content, being represented morphologically, is revealed in interaction with other factors in the process of morphological representation.

At the second stage, morphological forms activate the main characteristics in the content of morphological concepts. As a result, generalized morphological senses are formed. V. Evans and M. Green consider the elements of grammatical subsystem to perform a structuring function providing schematic meaning [Evans, Green 2006]. Because of their generalized character, these senses require further concretization described as the next stage of morphological representation. This concretization is revealed at the sentence-utterance level in interaction with linguistic factors. They are necessary to be taken into account, as the process of sense creation is always integrative and polyfactor. The principle of integrity (worked out by prof. N. Boldyrev in the functional and semiological approach [Болдырев 1995]), appears to be central for morphological representation. When we analyze morphological representation, the factors, influencing the process of a vast range of lexico-grammatical senses creation, turn out to be semantic, syntactic, and contextual. The semantic factor is connected with the semantics of the lexical units taking on this or that morphological category. The syntactic factor is associated with the syntactic structure of the sentenceutterance, the contextual one - with the nearest context of the whole sentence. Activation of the morphological concept by means of morphological forms simultaneously brings into action a primary concept. In the content of the latter, under the influence of the linguistic factors already mentioned, additional characteristics are profiled (high-lighted) within the correspondent cognitive domain. In some cases, linguistic factors may also activate some adjoining concepts.

The final stage of morphological representation is connected with the configuration of the conceptual content. Configuration, which is the process of shaping of the conceptual content by means of different variants of combination of the conceptual characteristics, in our case develops like this: activated characteristics of the morphological concept in combination with the profiled characteristics of the primary concept form the concrete lexico-grammatical senses revealed in the process of communication. The summary of our evidence regarding the creation of the lexico-grammatical senses in the process of morphological representation is presented in Figure 1.

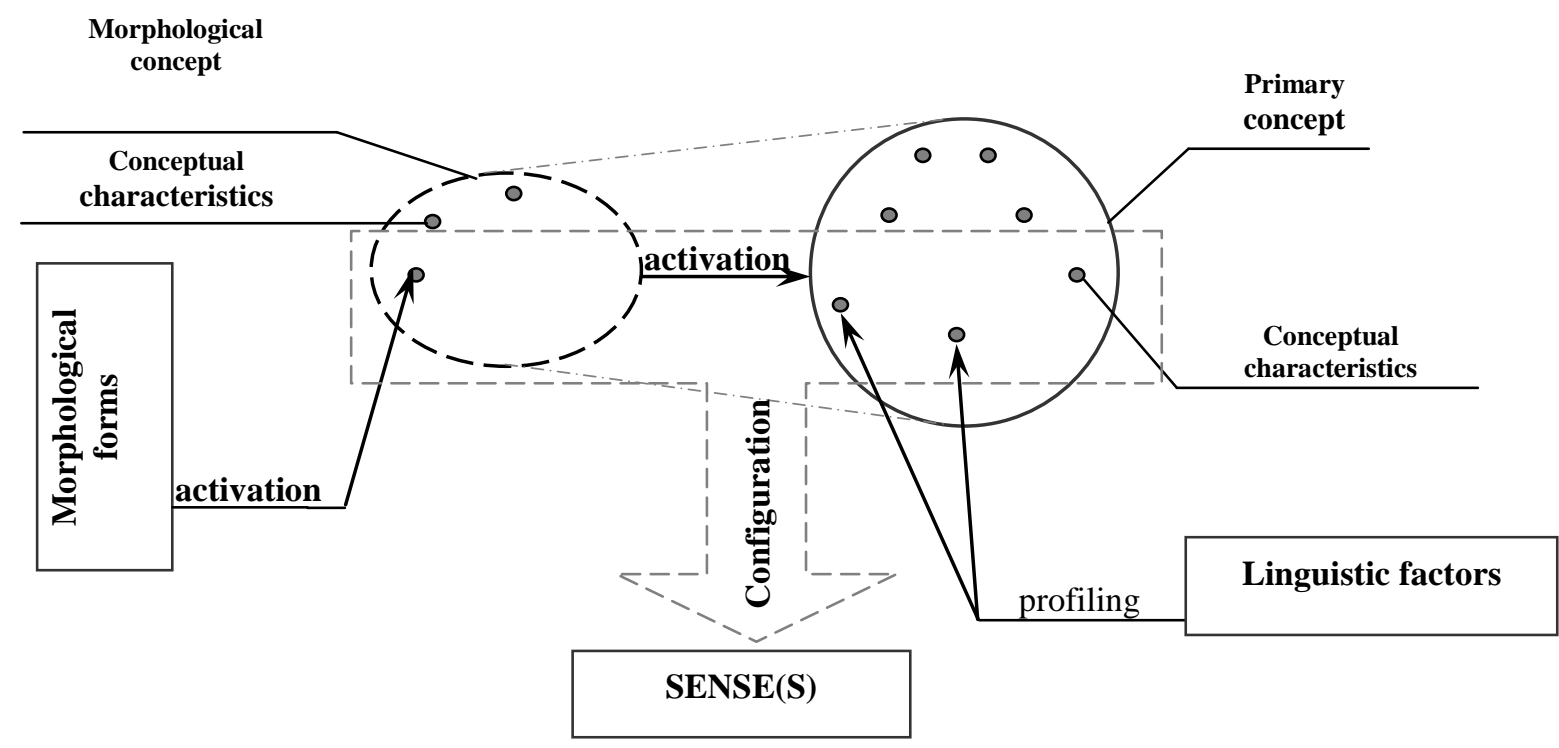

Figure 1. Creation of lexico-grammatical senses 
Further we will analyze the morphology of English tense in the perspective of morphological representation.

\section{Cognitive morphology of English tense}

Morphology represents time as divided into present, past and future. This division is embodied in the existence of the special morphological forms, both flexional and analytical in English. Conceptualization of TIME in morphology is carried out on the sentential level, with the conceptual content represented on the level of predicative relations (category of Tense) as well as on the level of subjectpredicate relations (category of Aspect).

At the first stage of morphological representation the morphological concept TENSE is formed. It is formed on the basis of the primary concept TIME from which characteristics 'present', 'past', 'future' are abstracted. These characteristics cause the appearance of morphological concept TENSE, which, in its turn, is treated as a cognitive basis for the same name morphological category. The content of the concept TENSE is revealed in its characteristics 'present' 'past', 'future', 'convertibility / inconvertibility', 'multidirectionality / unidirectionality', 'orderliness', 'panchronism', 'multidimensionality', 'duration', 'continuity / discontinuity', 'momentariness', 'simultaneity', 'priority', 'consecution', to name but a few (see [Беседина 2006]).

At the second stage, tense forms of the Past, Present and Future activate the morphological concept TENSE and characteristics 'simultaneity / priority / posteriority' in its content. As a result, corresponding morphological senses "simultaneity to the moment of speaking", "priority to the moment of speaking", "posteriority to the moment of speaking" are created. They are of the generalized (abstract) character. For instance, the form writes shows the reference of simultaneity, wrote - that of priority, will write - that of posteriority. In other words, the morphological forms of Past, Present and Future localize a situation either as simultaneous with the moment of speaking, or prior to the moment of speaking, or posterior to the moment of speaking, thus activating the corresponding morphological senses. In this case, they do not indicate that a situation takes place at some particular moment, prior to the moment of speaking or posterior to it; or that a situation takes place during some longer period of time or indefinite span of time, prior to the moment of speaking or posterior to it. The Past form, localizing a situation in the past, does not indicate if it lasts or does not last up to the present moment. Now we will illustrate the generalized morphological senses conveying:

- "simultaneity to the moment of speaking" I admire your patience that is encouraging (James $\mathrm{H}$. The Europeans).

- "priority to the moment of speaking" - Mr. Wentworth meditated (James H. The Europeans).

- "posteriority to the moment of speaking" We shall have a wedding, and I will write an epithalamium (James H. The Europeans).

Real communication, however, requires some specification and concretization of the morphological senses generalized. This concretization is achieved due to semantic and contextual factors in the process of communication. In this case, the uttermost importance, among the above-accentuated linguistic factors, is given to those of syntactic and contextual. Semantic factor influences the generalized morphological senses concretization in a less degree. In English, the peculiarities of understanding and language representation of such multilateral ontological entity as Time are presented by means of a complex system of aspect-tense forms, worked out in the course of historical development of the language. In this connection, we will further consider the aspect forms of the verb as one more additional linguistic factor in the process of creating the temporal lexico-grammatical senses.

Here the process is illustrated on the basis of the morphological tense forms (Figure 2).

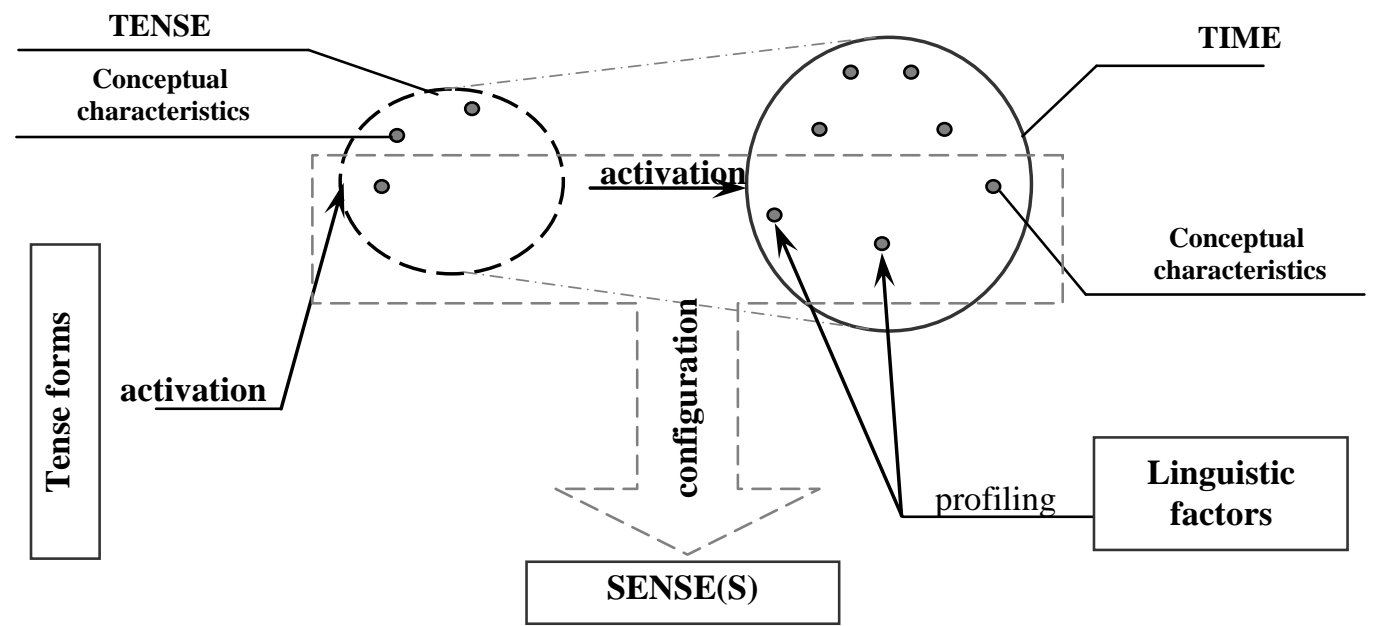

Figure 2. Creation of lexico-grammatical senses on the basis of tense forms 
Further we will show the creation of the main senses conveyed by the morphological forms of Past, Present and Future in the process of communication.

\subsection{Creation of the past senses}

The forms of the Past Tense, activating the morphological concept TENSE, activate the characteristic 'priority to the moment of speaking' in its content that leads to the creation of the generalized morphological sense "priority to the moment of speaking". The sense mentioned as well as the other morphological senses need to be specified and concretized. In the process of morphological representation, a number of lexico-grammatical senses are formed on the base of the forms of the past tense. They are: 'distant past', 'nearest past', 'progressive past'. It happens due to the influence of the additional linguistic factors.

Now the creation of one of these senses will be shown in detail. When forming the sense NEAREST PAST the tense forms of the Past (as the linguistic mechanism) activate the morphological concept TENSE and the characteristic "priority to the moment of speaking' in its content. This leads to the formation of the corresponding generalized morphological sense "priority to the moment of speaking". Then the latter is concretized under the influence of the contextual factor, presupposing the use of the adverbial modifiers of time pointing to the evident priority of the situation to the moment of speaking or to the slight temporal remoteness from it in the structure of the sentence (e. g. a moment ago, not long ago, some days ago, etc.).
This factor activates the primary concept TIME and profiles the characteristic 'past' in its content. The combination of two characteristics 'priority to the moment of speaking' in the content of the morphological concept TENSE and 'past' in the content of the primary concept TIME leads to the configuration of the conceptual content and creates the lexico-grammatical sense analyzed. The process is illustrated by the following examples and presented in Figure 3:

Sam phoned a moment ago (Alexander L.G.).

I had a word with Julian this morning (Alexander L.G.).

Further we are going to analyze the mechanisms and principles of creating other past senses.

DISTANT PAST indicates the distance of an event from the moment of speaking and the absence of the connection with it. The linguistic mechanism for this sense creation is Past Simple, which activates the characteristic 'priority to the moment of speaking' in the content of the morphological concept TENSE. This leads to the emergence of the generalized morphological sense "priority to the moment of speaking". The further specification and concretization of this generalized morphological sense is carried out under the influence of the contextual factor. It manifests itself in the presence of the adverbial modifiers of time, denoting the distance of the action from the moment of speaking. The use of the form, which locates the situation in the past, suggests that this situation has no connection with the present. Otherwise, the form of the present tense would be used. For instance,

The Goths invaded Rome in A.D. 410 (Alexander L.G.).

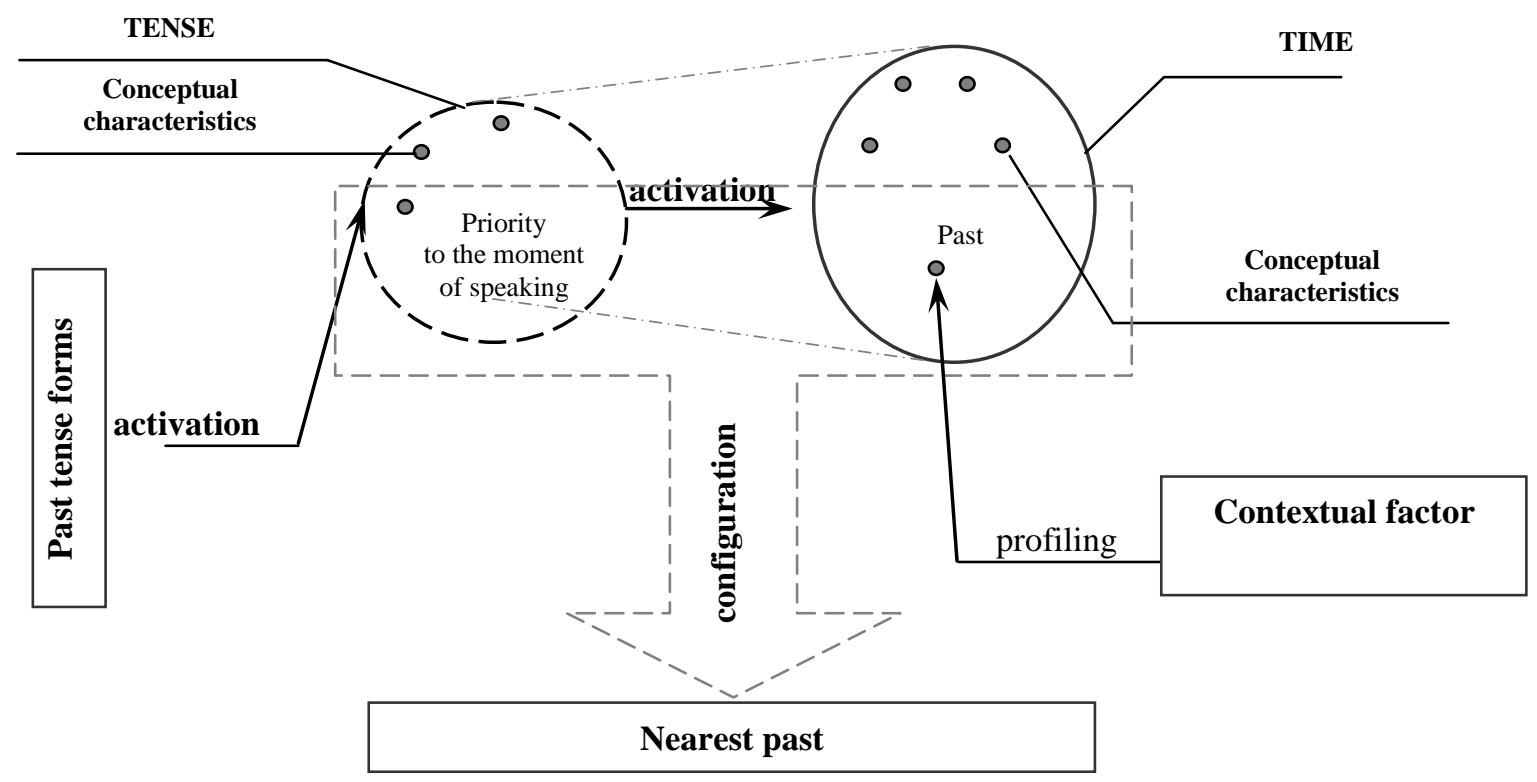

Figure 3. Creation of the sense "nearest past" 
Thus, under the influence of the contextual factor the characteristic 'irreversibility' is additionally profiled in the content of the primary concept TIME, which is activated simultaneously with the morphological concept TENSE. The combination of this characteristic with the characteristic 'priority to the moment of speaking' contributes to the configuration of the conceptual content and creates the grammatical sense "distant past".

DURATIVE PAST implies that some action took place either at a definite moment in the past or during some period of time in the past. Therewith there is no information if the action is in progress at this moment. The sense under analyses is formed on the base of the Past Progressive forms, which activate the morphological concept TENSE and the characteristic 'priority to the moment of speaking' in its content. This leads to the emergence of the generalized morphological sense "priority to the moment of speaking". Its specification is possible due to the influence of the contextual factor connected with the use of the adverbial modifiers of time or subordinate clauses of time, specifying the moment or period of the action. For instance,

I was working in a car factory during the summer of 1976 (Hewings M.).

When Carlo was in hospital we were visiting him twice a day (Hewings M.).

Under the influence of the contextual factor, the characteristic 'past' is additionally profiled in the content of the primary concept TIME, activated simultaneously with the morphological concept TENSE. The aspect forms can also influence this sense creation. In this case, it involves the use of the Progressive forms. They contribute to the activation of the morphological concept ASPECT and additionally profile the characteristic 'duration' in its content. Thus, the combination of the characteristics 'priority to the moment of speaking' of the morphological concept TENSE, 'past' of the primary concept TIME and 'duration' of the morphological concept ASPECT provides the configuration of the conceptual content and creation of the sense under analyses, in this case of grammatical character.

\subsection{Creation of the present senses}

The forms of the Present Tense are oriented, primarily, to the activation of the characteristic 'simultaneity to the moment of speaking' in the content of the morphological concept TENSE, it leads to the creation of the same name generalized morphological sense. For instance,

He lifted his hat and walked behind Kate and Juana. "He is following us!" whispered Juana (Lawrence D.H. The Plumed Serpent).
Its further specification is carried out in the sentence-utterance under the influence of the additional linguistic factors. As a result, the additional characteristics in the content of the primary concept TIME are profiled. The latter in combination with the characteristic 'simultaneity to the moment of speaking' of the morphological concept TENSE contribute to the configuration of the conceptual content and create the senses of grammatical character (primarily), and those of lexico-grammatical character (in individual cases). They are: "momentary present"; "durative present"; "generalized present", "resultative present"; "futural present". Further we will analyze the process of these senses creation.

MOMENTARY PRESENT, for instance, implies straightforward coincidence of the situation with the moment of speaking. The linguistic mechanism of this sense creation is the forms of the Present Simple and Present Progressive. They activate the morphological concept TENSE and the characteristic 'simultaneity to the moment of speaking' in its content, which leads to the creation of the corresponding generalized morphological sense. It is specified in the sentence-utterance under the influence of the syntactic and semantic factors. Besides, when concretization takes place, it is necessary to take pragmatic situation into account.

Thus, the forms of Present Simple and Present Progressive often express the sense under analyses in different kinds of reports, commentaries and demonstrations, the essence of which is to present the actions being watched or executed. For instance,

(Commentary at horse races) Red Rover crosses the finishing line (Comrie B.).

(Commentary at a football match) MacFee passes to Franklyn. Franklyn makes a quick pass to Booth. Booth is away with the ball, but he is loosing his advantage (Alexander L.G.).

Time in this case appears as a succession of events. The role of the syntactic factor involves using the form of Present Simple in a particular model of the sentence, namely in the sentence with the homogeneous predicates or in compound sentences. The concretization of the generalized morphological sense also happens with the involvement of the aspect forms of Progressive and Simple. For instance,

First I put a lump of butter into a frying pan and light the gas, then I break three eggs into a bowl (Swan M.).

When expressing the sense "momentary present", the pragmatic factor appears to be meaningful in some cases. It implies the necessity to take the pragmatic focus of the utterance as well as semantic 
factor into account. Here we refer to, so called, performatives and actions they express. It is mostly realized by means of the locutionary verbs in the form of Present Simple. For instance,

I declare this exhibition open (Alexander L.G.).

'I congratulate you!' said Felix, smiling (James H. The Europeans).

So, under the influence of the additional linguistic factors the additional characteristic 'momentariness' is profiled in the content of the primary concept TIME. Its combination with the characteristic 'simultaneity to the moment of speaking' of the morphological concept TENSE contributes to the conceptual content configuration and creates the basis for the lexico-grammatical sense under analyses.

DURATIVE PRESENT implies states and processes, which are taking place at the moment of speaking, but have started before this moment and will continue after it. In other words, here we mean the events lasting for a longer period of time than the moment of speaking itself. However, the moment of speaking itself is included into this period of time. This sense is based on the Present Progressive form. This form activates the characteristic 'simultaneity to the moment of speaking' in the content of the morphological concept TENSE, which leads to the generalization of the corresponding morphological sense. Its specification and concretization are realized under the influence of the aspect form and contextual factor. The latter implies the use of the adverbial modifiers of time pointing at the length of the period of time during which the action is performed as well as the general situational context. It is connected with the fact that nonterminability of the situation by the moment of speaking cannot be expressed properly morphologically. For instance,

The author is working on chapter two (Comrie B.).

"All right", I said. "But don't forget he's looking for her and she's a man who would bear down (Chandler R. Farewell, My Lovely).

The aspectual characteristics play an important role while forming this sense, which explains the use of the Progressive forms. Semantic and grammatical peculiarities of the verb are also of great importance here, as the sense under analyses is expressed by the verbs in non-terminative meanings only. Beyond that, in such cases it is essential to take the knowledge about the world (background knowledge) into account, to interpret this situation as referring to a wider period of time, including the moment of speaking.

We consider the repetitive actions, understood as an aggregate lasting situation as a particular case of the sense under analyses. In this case, the continui- ty of the process and its incompleteness are accentuated. It is achieved due to the use of the verbs of corresponding semantics (the verbs expressing the repetitive actions), i.e. the semantic factor as well as the contextual one. The influence of the latter is connected with the use of the adverbs, denoting the continuous action, and nouns in their plural form in the function of object. For instance, ings M.).

Why are you jumping up and down? (Hew-

"Business is still making efforts to recover from the war years", he said (McDermott $\mathrm{A}$. Charming Billy).

Thus, under the influence of the above analyzed linguistic factors the characteristic 'present' is additionally profiled in the content of the primary concept TIME. Under the influence of the aspect form the morphological concept ASPECT gets its activation and the characteristic 'duration' is profiled in its content. It is the combination of these characteristics with the characteristic 'simultaneity to the moment of speaking' of the morphological concept TENSE that contributes to the conceptual content configuration and creates the grammatical sense 'durative present'.

GENERALIZED PRESENT implies present actions taking part irrelatively to the moment of speaking, i.e. habitual repeated, usual actions, statement of the facts, accepted truth, laws of nature and society. For instance,

I leave work at 5.30 most days (Hewings M.).

Ultra-violet. It makes certain metallic inks glisten in the dark (Chandler R. Farewell, My Lovely).

The possibility of such grammatical understanding of the actions under analyses can be explained by the fact that for a speaker they are the actual characteristics of the objects, actual for the moment of speaking due to their stability and unalterability (see: [Петрухина 2005]). The action in cases like that does not refer to a particular temporal plan, though it does not mean that it is understood as nontemporal, as generalized action input in the generalized (non-limited) time (see: [Иванова 1961]). As it can be seen from the examples above, these senses are formed on the basis of the Present Simple form. The latter activates the morphological concept TENSE and the characteristic 'simultaneity to the moment of speaking' in its content. As a result, the same name morphological sense is created. The contextual factor performs the leading role in this process. It is manifested in the use of the adverbial modifiers of time, frequency, denoting the periodicity, repetitiveness of the actions. To state the facts the 
verbs to be, to have in the form of Present Simple are used. In this case the features and properties of somebody or something, actual for the moment of speaking are conceptualized. For instance,

Only a neurotic woman faints when someone attacks her; a strong-minded woman knows that this is no solution (Wilson C. The Mind Parasites).

Thus, in the process of this sense creation the characteristic 'panchrony' is profiled in the content of the primary concept TIME under the influence of the contextual factor. It is the combination of the characteristics 'simultaneity to the moment of speaking' of the morphological concept TENSE and that of 'panchrony' of the primary concept TIME that contributes to the conceptual content configuration and creation of the sense 'generalized present'.

The form of Present Perfect is the base for creation of the sense RESULTATIVE PRESENT. Here it implies the actions performed in the past and connected with the moment of speaking through their result, which highlights the salience of the result of the action for the moment of speaking. For instance,

Prices have decreased by $7 \%$ (Hewings M.).

In this case the morphological form of Present Perfect activates the morphological concept TENSE, and the characteristic 'simultaneity to the moment of speaking' in its content. It leads to the formation of the corresponding morphological sense. Then the latter is concretized under the influence of the contextual factor, presupposing the use of the adverbial modifiers of time pointing to the completeness of the action by the moment of speaking.

As a particular case, we distinguish the actions, which took place in the past in relation to the moment of speaking, but connected with it through the mutual period of time. The base for this sense is the Present Perfect. The additional influence of the contextual factor manifests itself by use of the lexical means indicating the period of time. For instance,

They've had a dozen chances to look you over since (Chandler R. Farewell, My Lovely).

Besides, the aspect form of the verbs plays an important role in creation of this sense, as well as the semantic factor does. The latter manifests itself in the use of the verbs in the Present Perfect form in nonterminative meanings. While the sense under analyses is created, the characteristic 'present' is profiled additionally in the content of the primary concept TIME. It happens under the influence of the contextual factor. The aspect form activates the morphological concept ASPECT and additionally profiles the characteristic 'resultativeness' in its content.
The analyses of the senses formed on the basis of the present tenses forms we have carried out, allow confirming their ability to express the senses of different degrees of generality. Thus, the present can be conceptualized in language both as some point and as a period of indefinite duration. This is manifested by the fact that while creating the different senses on the base of the forms of the present the characteristics 'panchrony', 'momentariness', 'future', 'present' are profiled in the content of the primary concept TIME, and the characteristics 'resultativeness' and 'duration' are profiled in the content of the morphological concept ASPECT, the latter also being formed on the base of the primary concept TIME.

\subsection{Creation of the future senses}

The forms of the Future Tense activate the generalized morphological sense "posteriority to the moment of speaking". This sense, being maximally abstract, gets its specification and concretization at the sentenceutterance level. It happens due to the influence of the syntactic and contextual factors and it also presupposes taking the aspectual characteristics of the situations under analyses into account. Therewith different methods to localize the situations in future exist. In particular, they can take place after the moment of speaking; their beginning is counted from the moment of speaking; or the situations begin before the moment of speaking, continue at the moment of speaking and after it, etc. As a result of the additional linguistic factors' influence, the characteristics are profiled in the content of the primary concept TIME. In combination with the characteristic 'posteriority to the moment of speaking' of the morphological concept TENSE, they initiate configuration of the conceptual content. On this basis the grammatical and lexico-grammatical senses as follows are formed: "distant future", "nearest future", "resultative future", "durative future". Further, we will show some details of creating these senses.

DISTANT FUTURE implies the reference to the fact of performance of this or that action irrespectively of a particular moment or period of time, following the moment of speaking. For instance,

You will walk differently alone, dear, through a thicker atmosphere forcing your way through the shadows of chairs, through the dripping smoke of the funnels. You will feel your own reflection sliding along the eyes of those who look at you (Fitzgerald F.S. Tender Is the Night).

In this case, a succession of events in the $\mathrm{Fu}$ ture, unrestricted by some time span, or statements of a common sense, stated as a hypothesis or presupposition, act as a particular sense. For instance, 
You will get to know me more and more as the days go by and, in time, you will come to understand what you have seen (Girzone J.F. Joshua. A Parable for Today).

People will live longer in future (Hewings M.).

As these instances show, the form of Future Simple serves as the linguistic mechanism of the sense under analyses creation. This form, activating the morphological concept TENSE in the process of morphological representation, activates the characteristic 'posteriority to the moment of speaking' that leads to the emergence of the same-name morphological sense, which is further specified and concretized in the sentence-utterance under the influence of the contextual factor. In this case, the contextual factor implies the presence of the adverbial modifiers of time pointing at the time span, remoted from the moment of speaking (e.g. in future, in time, etc.). Under the influence of this linguistic factor the characteristic 'irreversibility' is additionally profiled in the content of the primary concept TIME. Its combination with the characteristic 'posteriority to the moment of speaking' enables configuration of the conceptual content and creation of the sense under analyses.

NEAREST FUTURE implies the future actions immediately following the moment of speaking. This sense is based on the Future Simple form, which activates the morphological concept TENSE and its content characteristic 'posteriority to the moment of speaking' in the process of morphological representation. This leads to the emergence of the morphological sense "posteriority to the moment of speaking". Further this generalized sense is concretized under the influence of the contextual factor, implying the presence of the adverbial modifiers of time or subordinate clauses of time, pointing at the immediate consecution of the action after the moment of speaking (e.g. soon, in 5 minutes, in some days, later, etc.). For instance,

"Do you have to go?" "Now or later." "All right. Now." "I'll come back later." "I'll have finished the papers," I said (Hemingway E. A Farewell to Arms).

In five minutes you'll be perfectly well (Maugham W.S. The Painted Veil).

The influence of the contextual factor leads to the additional profiling of the characteristic 'future' in the content of the primary concept TIME. Its combination with the characteristic "posteriority to the moment of speaking' of the morphological concept TENSE results in configuration of the conceptual content and the sense under analyses creation.
RESULTATIVE FUTURE denotes an action that will be completed by the definite moment, following the moment of speaking. In this case the beginning of the action cannot at all be connected with the moment of speaking. As a rule, this sense is expressed by means of the Future Perfect form. This form activates the morphological concept TENSE and the characteristic "posteriority to the moment of speaking' in its content. This leads to the emergence of the morphological sense "posteriority to the moment of speaking". Its concretization is carried out by means of the contextual factor in the sentenceutterance. Here, this linguistic factor employs the adverbial modifiers of time with prepositions by, till, until, etc. or subordinate clauses of time introduced with the help of conjunction by. For instance,

They will have completed the new bridge by the end of the year (Alexander L.G.).

By the time you get home I will have cleaned the house from bottom to top (Hewings M.).

Thus, under the influence of the contextual factor the characteristic 'future' is additionally profiled in the content of the primary concept TIME. The aspect form of the verb can be of great importance when creating this sense. It additionally activates the morphological concept ASPECT and profiles the characteristic 'resultativeness' in its content. As a result, the combination of the characteristics 'priority to the moment of speaking' of the morphological concept TENSE, 'future' of the primary concept TIME and 'resultativeness' of the morphological concept ASPECT initiates configuration of the conceptual content and provides creation of the sense under analyses.

DURATIVE FUTURE expresses a durative action that will take place at a definite moment or period of time, following the moment of speaking. For instance,

This time next week I'll be lying in the sun of one of the most hot islands in the world (Hewings M.).

Situations, the beginning of which is coincident with the moment of speaking, but their basic phase has not been realized yet and will continue after the moment of speaking, constitute an individual sense. For instance,

That oak tree will still be standing there fifty years from now (Thomson A.J., Martinet A.V.).

One more variation of the continuous action that will take place in future is the actions the beginning of which is prior to the moment of speaking, but they themselves will continue after the moment of speaking up to the definite moment in future. For instance, 
They will have been married for thirty years in August (McDermott A. Charming Billy).

Next Christmas I'll have been teaching for twenty years (Swan M.).

The instances presented consider the forms of Future Progressive and Future Perfect as a linguistic mechanism of the sense "durative future" creation. In the process of morphological representation they activate the morphological concept TENSE and the characteristic 'posteriority to the moment of speaking' in its content. This leads to the emergence of the samename morphological sense. Then, in the sentenceutterance, this sense gets its concretization under the influence of the contextual factor, which employs the adverbial modifiers of time pointing at the definite moment or period of time in future. The influence of the contextual factor results in additional profiling of the characteristic 'future' in the primary concept TIME. The aspect form of the verb is also of significant role when creating this sense. It affects activation of the morphological concept ASPECT and profiling of the characteristic 'duration' in its content. Thuswise, the combination of the characteristics 'posteriority to the moment of speaking' of the morphological concept TENSE, 'future' of the primary concept TIME and 'duration' of the morphological concept ASPECT lay the foundation for configuration of the conceptual content and leads to the creation of the sense "durative future".

Thus, when forming the distinguished above senses on the basis of the forms of the future tense, the characteristics 'future' and 'irreversibility' are profiled in the content of the primary concept TIME due to the influence of the additional linguistic factors elicited. In their turn, the characteristics 'resultativeness' and 'duration' are profiled in the content of the morphological concept ASPECT.

\section{Conclusion}

In our approach we have laid special emphasis on the fact that the possibility for morphological forms to express different senses in the process of communication is caused by conceptual processes which underlie the morphological representation as a categorical way of structuring conceptual content. The analysis of tense morphology on cognitive grounds has allowed us to account for some properties of morphological categories using the theory of morphological representation developed in cognitive linguistics. Such a perspective on English tense appears to demonstrate that senses' creation can be affected by the conceptual modifications which lead to configuration of conceptual content in order to meet changing communicative and cognitive needs. Morphological forms of tense express various senses relying on general cognitive mechanisms like abstraction, profiling, configuration. The cognitive basis of tense forms use is exploitation of encyclopedic knowledge in its interaction with linguistic knowledge.

Thus, we have fulfilled the analyses of the grammatical and lexico-grammatical senses. The generalized morphological temporal senses underlie them. The results of the analyses obtained give evidence of the mutually complimentary influence of the temporal and aspectual characteristics in the process of morphological representation. This fact simultaneously implies the necessity to distinguish and specify the senses which are different in their conceptual base, i.e, which are created on the basis of different generalized morphological senses. Such a differentiation has been carried out in this paper with the research aims only. Evidence presented in the paper have proved that the creation of the grammatical and lexicogrammatical senses in the process of morphological representation is possible due to the configuration of the content of the primary concept TIME that leads to the diverse variations in combination of characteristics both of the primary concept and morphological one.

\section{References}

Alexander L.G. Longman English Grammar. L.; N.Y.: Longman, 1997.

Besedina N., Stepanenko S., Fedotova $O$. \& Sherstyokova $Y$. Morphology of Number in English: a Cognitive Perspective // Journal of Language and Literature. 2014. 5 (3). P. 83-88.

Chandler R. Farewell, My Lovely. М: Менеджер, 2000.

Clausner T.C., Croft W. Domains and Image Schemas // Cognitive Linguistics. 1999. 10 (2). P. 1-31.

Comrie B. Tense. Cambridge: CUP, 1986.

Evans V., Green M. Cognitive Linguistics: An Introduction. Edinburgh: Edinburgh University Press, 2006.

Fitzgerald F.S. Tender Is the Night. London: Penguin Popular Classics, 1997.

Girsone J.F. Joshua. A Parable for Today. N.Y.: Macmillan Publishing Company, 1987.

Hemingway E. A Farewell to Arms. M.: Progress Publishers, 1976.

Hewings M. Advanced Grammar in Use. Cambridge: CUP, 2000.

Jackendoff $R$. Semantics and Cognition. The MIT Press, 1984.

James $H$. The Europeans. Hertfordshire: Wordsworth Editions, 1995.

Lawrence D.H. The Plumed Serpent. Wordsworth Editions Limited, 1995. 
Maugham W.S. The Painted Veil. N.Y.: Penguin Books, 1998.

McDermott A. Charming Billy. N.Y.: Dell Publishing, 1999.

Swan M. How English works. Oxford: OUP, 1997.

Taylor J. Linguistic Categorization: Prototypes in Linguistic Theory. Oxford University Press, 1995.

Thomson A.J., Martinet A.V. A Practical English Grammar. Oxford: OUP, 1997.

Wilson C. The Mind Parasites. M.: Raduga Publishers, 1986.

Беседина Н.A. Концептуальное пространство морфологии // Концептуальное пространство языка: сборник научных трудов. Посвящается юбилею профессора Н.Н. Болдырева. Тамбов: Изд-во ТГУ им. Г.Р. Державина, 2005. С. 149-156.

Беседина Н.А. Морфологически передаваемые концепты: дис. ... д-ра филол. наук. Тамбов, 2006.

Беседина Н.А. Языковое знание и морфология как способ его репрезентации // Типы знаний и их репрезентация в языке: сборник научных трудов. Тамбов: Издательский дом ТГУ, 2007. C. 28-37.

Беседина Н.A. Уровни концептуализации в морфологии // Когнитивные исследования языка. 2009. Вып. IV. C. 182-231.
Беседина Н.А. Когнитивное варьирование как основа взаимодействия лексики и грамматики в языке // Когнитивные исследования языка. 2014. Вып. XIX. C. 154-160.

Беседина Н.A. Концептуально-репрезентативный анализ как метод изучения морфологической репрезентации в языке // Сибирский филологический журнал. 2011. Вып. 1. С. 178-183.

Болдырев Н.Н. Функциональная категоризация английского глагола. СПб.; Тамбов, 1995.

Болдырев Н.Н. Когнитивная семантика. Введение в когнитивную лингвистику: курс лекций. 4-е изд., испр. и доп. Тамбов: Издательский дом ТГУ им. Г.Р. Державина, 2014.

Иванова И.П. Вид и время в современном английском языке. Л.: Изд-во ЛГУ, 1961.

Кубрякова Е.С. Язык и знание: На пути получения знаний о языке: Части речи с когнитивной точки зрения. Роль языка в познании мира. М., 2004.

Кубрякова Е.С., Демьянков В.З. К проблеме ментальных репрезентаций // Вопросы когнитивной лингвистики. 2007. № 4. С. 8-16.

Петрухина Е.B. Когнитивные модели времени в русской грамматике // Концептуальное пространство языка: сборник научных трудов. Посвящается юбилею профессора Н.Н. Болдырева. Тамбов: Изд-во ТГУ им. Г.Р. Державина, 2005. С. 111-128.

\title{
КАТЕГОРИЯ ВРЕМЕНИ В АНГЛИЙСКОМ ЯЗЫКЕ С КОГНИТИВНОЙ ТОЧКИ ЗРЕНИЯ
}

\author{
Н.А. Беседина, С.Н. Степаненко, О.В. Федотова \\ Белгородский государственный национальный исследовательский университет (Белгород, Россия) \\ SStepanenko@bsu.edu.ru
}

\begin{abstract}
В статье представлена когнитивная интерпретация английской категории времени, позволяющая установить и описать механизмы взаимодействия единиц концептуального и языкового уровней. Авторы на основе анализа фактического материала показывают, как изменения в семантике английских временных форм, возникающие на основе процессов конфигурирования концептуального содержания, создают предпосылки для передачи широкого спектра лексико-грамматических смыслов, имеющих категориальный статус, в процессе коммуникации.
\end{abstract}

Ключевые слова: английская морфология, временные формы, модель морфологической репрезентации, морфологически передаваемый концепт, когнитивный механизм, лингвистические факторы, принцип интегративности, конфигурирование, абстрагирование.

Для цитирования: Besedina N.A., Stepanenko S.N., Fedotova O.V. Morphology of Tense in English: View from Cognitive Linguistics // Boпросы когнитивной лингвистики. 2019. № 3. С. 85-95. 